\title{
EFFECTS OF FOLIAR FERTILIZATION OF COMMON BEAN (Phaseolus vulgaris, L.) IDURING THE SEED-FILLING STAGE $(*)$
}

\author{
A.M.L. NEPTUNE ** and T. MURAOKA ***
}

\section{SUMMARY}

An experiment was carried out with common bean (Phaseolus vulgaris, L.) in a Red Yellow Latossol, sandy phase, in order to study the influence of foliar spraying of the Hanway nutrient solution (NPKS) at grain filling stage on: 1) grain yield; 2) the uptake of fertilizer and soil nitrogen by this crop through the root system and 3) the efficiency of utilization of the nitrogen in the foliar spray solution by the grain.

The results of this experiment showed that the foliar application of the Hanway solution with ammonium nitrate at the pod filling period caused severe leaf burn and grain yield was inferior to that of the plants which received a soil application of this fertilizer at the same stage. These facts can be attributed to the presence of ammonium nitrate in the concentration used. The composition of final spray was: $114,28 \mathrm{Kg} \mathrm{NH}_{4} \mathrm{NO}_{3}+$ $43,11 \mathrm{Kg}$ potassium poliphosphate $+12,44 \mathrm{Kg}$ potassium sulphate per 500 litres.

The uptake of nitrogen fertilizer through the root system and the efficiency of its utilization was greater than that through the leaves.

\section{INTRODUCTION}

The term "foliar fertilization" refers to the application of fertilizers by spraying or dusting the leaves of the plants. This term still implies

* Received for publication in 30 December 1977.

This paper was supported under a Research Agreement, by the Joint FAO/IAEA Division of Agriculture of the International Atomic Energy Agency and the Comissão Nacional de Energia Nuclear, Brazil.

* USP-ESALQ-Centro de Energia Nuclear na Agricultura e Departamento de Solos, Geologia e Fertilizantes - Caixa Postal 96 - 13400 Piracicaba, SP Brasil.

*** USP-ESALQ-Centro de Energia Nuclear na Agricultura (CENA). Bolsista do CNPq The authors wish to express sincere appreciation to Mr. Osmar F. de Paula, Mr. João O. Salvador, Miss Marileuza A. Bassi, Mr. Rudinei A. Romani and Mr. Alcides de Araujo, for thei valuable assistance in the field and laboratory work and to the Divisão de Ciências Ambientais do CENA, for the cooperation. 
the nutrients uptake contained in the fertilizers and their utilization in useful compounds for the plant growth. Until certain extent this term is not correct, once all the parts of the plants can absorb nutrients: flowers, pcds, fluits, branches, stem, trunk, etc. But, as the leavese present a greater exposition surface, the term "foliar fertilization" prevailed.

GRIS, 1844 e 1847, a french researcher, was the first who sprayed an iron solution in plants and corrected by this practice this deficiency. During almost one century, the foliar fertilization was neglected.

In 1930 , more attention, was given to this new fertilizer practice.

In recent years, many experiments have been conducted to determine the effects of foliar sprays containing macronutrients on various crops. Results have been inconsistent. In Brazil, some research workers were worried about the use of this fertilization technique (process), even before the advent of polyphosphates. (NEPTUNE, et al., 1967; CROCOMO and NEPTUNE, 1961; BUENDIA e NEPTUNE, 1971; SILVA, 1969; NEPTUNE, et al., 1961; BULISANI et al., 1973a e b).

However, foliar application of primary nutrients is feasible in some situations for certain crops which need pesticides during their growth cycle.

The greatest applicability of foliar sprays was for micronutrient to fruit trees, coffee trees, ornamental and vegetable crops, all of which of high crops value.

Since 1974, experiments have been carried out using potassium polyphosphates, urea and a small amount of sulphate source in solutions as a faliar spray on soybeans, in the United States by Allied Chemical Corporation and IIowa State University. Polyphosphates sources were preferred over orthophosphates in view of the work by BAREL and BLACK quoted by GRAY, 1977, showing that polyphosphates caused less leaf burning. In February 1975, Allied Chemical Corporation has conducted some experiments in Brasil, in the State of Parana. At the Iowa State University, a potassium polyphosphate solution (0-26-25) made in TVA plant, was used by GARCIA and HANWAY, 1976. The merit of these investigators consisted of finding out the seed filling period of soybean as the best stage for foliar spraying. The explication given was the following: during the pod filling period, photosynthates produced in plant leaves are translocated to developing seed. Without food from the leaves, the roots are starved (stop growing), nodules die and uptake of most nutrients slows and stops. Therefore, addition of nutrients to the leaves at this stage may prevent nutrient depletion, keep the leaves more active in carryinb photosynthesis and increase seed yields (HANWAY, 1962). 
The results obtained by GARCIA and HANWAY, 1976, from the 2 years of field experimentation demonstrate conclusively that soybeans yields can be significantly increased by foliar application of an NPKS solution. The experimental data indicate that for such foliar application to $b$ e most effective, they must supply all four of the nutrients, NPKS, maling two or four applications, between the stage where beans were beginning to develop and could be felt when the pod was squeezed and the stage where beans were physiologically mature, i.e. $50 \%$ of the leaves were yellow.

In order to verify if the benefits obtained with soybean, could be obtained with common bean (Phaseolus vulgaris, L.), this experiment was conducted to study the influence of foliar spraying of the Hanway nutrient solution (NPKS) at grain fillings stage on: 1) the efficiency of utilization of the nitrogen in the foliar spray solution by the grain, 2) the uptake of fertilizer and soil nitrogen by the crop through the root system, and 3) grain yield.

\section{MATERIAL AND METHODS}

\section{Experimental Design}

The treatments given below, in number of eight were laid down in a $R B D$ replicated 5 times.

Treatments

1

2

3

4

5

6

7

8
At seeding (Soil addiisation)

PK

PK

$\mathrm{PK}+{ }^{15} \mathrm{NH}_{1}{ }^{15} \mathrm{NO}:$

(30 kg N/ha)

$\mathrm{PK}+\mathrm{NH}_{4} \mathrm{NO}_{3}$ (unlabelled)

(30 kg N/ha)

Idem - Treatment 3

Idem - Treatment 4

Idem - Treatment 4

Absolute control (without NPK)
At the pod filing stage (Foliar spray or Soil application) .

Foliar spray-Hanway Solution, with ${ }^{15} \mathrm{NH}_{4}{ }^{15} \mathrm{NO}_{3}$

Foliar spray-Hanway solucion with unlabelled $\mathrm{NH}_{4} \mathrm{NO}_{3}$

Ide $\mathrm{m}$ - Treatment 4 ${ }^{15} \mathrm{NH}_{4}{ }^{15} \mathrm{NO}_{3}$ applied in Soil as top dressing ( (30 kg N/ha)

Idem - Treatment $6+$ + Treatment 4. 
The original plan was not followed because we were not be able to import urea- ${ }^{15} \mathrm{~N}$. The alternative was to carry out the experiment, substituting urea by ammonium nitrate- ${ }^{15} \mathrm{~N}$, with $1,5 \%$ atoms of ${ }^{15} \mathrm{~N}$ in excess, the only tagged nitrogen fertilizer that was available.

Plot layout

Each treatment plot consisted of 7 rows. The plot dimensions were $10 \mathrm{~m}$ lenght and $3.5 \mathrm{~m}$ width. The planting distances was $8-10 \mathrm{~cm}$ within the row and $50 \mathrm{~cm}$ between the row.

The N-15 labelled fertilizer and/or N-15 labelled foliar spray solution was applied to subplot with 2.56 lenght and $1.0 \mathrm{~m}$ width. Unlabelled nitrogen fertilizer was applied to the rest of the plot outside the subplot demarcated for N-15 labelled fertilizer.

Soil used and its analysis

The soil used is a Red Yellow Latossol, sandy phase, of the Experimental Field, of the Department of Soils and Fertilizers, ESALQ, Piracicaba, State of São Paulo.

Composite soil samples from the experimental site, at different depths, were taken for physical and chemical analysis. The moisture determination was made by the gravimetric method. (Table I).

Table I - Soil analysis of the experimental site at different depths.

\begin{tabular}{|c|c|c|c|c|c|c|c|c|c|c|c|c|}
\hline \multirow[b]{2}{*}{$\stackrel{\vec{\Xi}}{\stackrel{\Xi}{\Delta}}$} & \multirow[b]{2}{*}{ 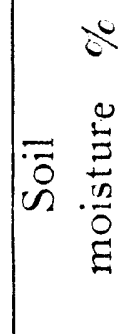 } & \multirow[b]{2}{*}{ 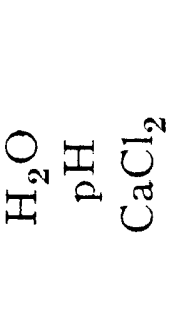 } & \multirow[b]{2}{*}{$\begin{array}{l}z \\
\overline{3} \\
0 \\
0\end{array}$} & \multirow[b]{2}{*}{ 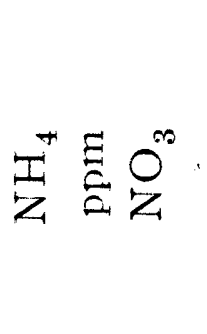 } & \multicolumn{8}{|c|}{$\mathrm{me} / 100 \mathrm{~g}$ soil } \\
\hline & & & & & 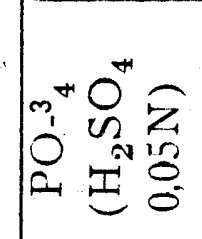 & 壬 & $\underset{⿱ 乛}{+}$ & $\stackrel{+}{m}$ & $\underset{\pi}{+}$ & $\underset{\sim}{+}$ & $\begin{array}{l}+ \\
+ \\
\tilde{U}\end{array}$ & $\begin{array}{l}+ \\
+ \\
+0 \\
=0\end{array}$ \\
\hline $0-20$ & 15.2 & 5.2 & 0.12 & 2.52 & 0.15 & 3.1 & 0.68 & 0.46 & 0.03 & 0.2 & 1.2 & 0.3 \\
\hline $20-40$ & 17.9 & 5.1 & 0.10 & 1.85 & 0.10 & 3.0 & 0.79 & 0.48 & 0.03 & 0.2 & 1.2 & \\
\hline $40-60$ & 20.0 & 5.0 & 0.10 & 2.15 & 0.02 & 3.2 & 0.99 & 0.64 & 0.03 & 0.1 & 1.3 & 0.3 \\
\hline
\end{tabular}

The $\mathrm{pH}$ value was determined by a glass electrode in soil: $\mathrm{H}_{2} \mathrm{O}$ ratio and soil: KC1 ratio, 1:2.5; organic carbon by the method of WALKLEY and BLACK, as described by JACKSON, 1956, total nitrogen by the semi-micro Kjeldahl procedure described by BREMNER, 1965, nitrate and "excrangeable" ammonium by the magnesium oxide-Devarda 
alloy methods, described by BREMNER, 1965; soluble phosphorus was determined by photocolorimetric method after extraction with $\mathrm{H}_{2} \mathrm{SO}_{4}$ $0,05 \mathrm{~N}$; exchangeable potassium was determined by flame photometry after extraction with a solution of $\mathrm{KC} 10.05 \mathrm{~N}$; exchangeable calcium and magnesium were determined in the flame spectrophotometer of absorption after extraction with a solution of KC1 $1 \mathrm{~N}$; exchangeable aluminium was titrated with a solution of $\mathrm{NaOH} 0.02 \mathrm{~N}$ after extraction with a solution of $1 \mathrm{KC1} 1 \mathrm{~N} ; ;$; and exchangeable hidrogen was titrated with $\mathrm{Na} 0 \mathrm{H} 0.02 \mathrm{~N}$ after extraction with calcium acetate $1 \mathrm{~N}$, adjusted to $\mathrm{pH}$ 7.0.

\section{Cultivar used}

Tris cultivar (local name: feijão Carioca) is a plant with indetermined growing habit, long peduncle and a growth cycle around 90 days. D'ARTAGNAN et al., 1971 pointed out that good yields have been obtained by the producers with this cultivar, which shows a great resistance to diseases.

Seed inoculation and sowing

The seeds were inoculated with strains and sowing took place on November $12^{\text {th }}$ and emergence of plants occurred on November $22^{\text {th }}$. The strain used were $127-\mathrm{K}-14$ and $127-\mathrm{K}-17$ from Nitragin Co., USA and a strain, called CENA-04.

\section{Soil fertilizers application}

The entire experimental plots were uniformly treated before sowing, with $100 \mathrm{~kg} \mathrm{P}_{2} 0_{5} / \mathrm{ha}$ as ordinary superphosphates and $60 \mathrm{~kg}$ $\mathrm{K}_{2} \mathrm{O} /$ ha as potassium chloride.

The plots of the treatments $3,4,5,6$ and 7 received, at seeding, 30 $\mathrm{kg} \mathrm{N} /$ ha, as ammonium nitrate, except that treatments 3 and 5 received labelled ammonium nitrate. All the fertilizers were applied in banding. The treatments 6 and 7 received, at the pod filling stage a top dress application of labelled ammonium nitrate $(30 / \mathrm{kg} \mathrm{N} / \mathrm{ha})$.

\section{The foliar nutrient spray}

The composition of the Hanway nutrient solution for the foliar spray treatment was: $80 \mathrm{~kg} \mathrm{~N}$ (as ammonium nitrate unlabelled or labelled with $1.5 \%$ atoms of ${ }^{15} \mathrm{~N}$ in excess), $22.42 \mathrm{~kg} \mathrm{P}_{2} \mathrm{O}_{5}$ (as potassium polyphosphate), $31.38 \mathrm{~kg} \mathrm{~K} \mathrm{~K}_{2} \mathrm{O}$ (as potasium polyphosphate) and 4.48 $\mathrm{kg}$ S (as potassium sulfate) per 1000 litres.

This solution was sprayed twice at 250 litres/ha per spray, spaced at 10 days apart during the grain filling stage. The first spraying was 
done on Januaryt $12^{\text {th }}$ when the beans began to develop and could be belt when the pods were squeezed, and the second and last, on January $21^{\text {th }}$, when the pods were yellowing, and $50 \%$ of the leaves were yellow.

The N-15 labeled solution was sprayed on the inside parts of rows 4 and 6 falling within the N-15 sub-plot and on the whole of row 5 in this sub-plot. The unlabelled solution was applied to rest of the plants in the treatment plot, including the whole of Rows $1,2,3$, and 6 , and the outside parts of rows 4 and 6 falling outside the N-15 sub-plot.

The sprayings was carried out early in the morning. Treatment plots not receiving the nutrient sclution spray was similary sprayed with an equal volume of water.

\section{Harvesting}

An intermediate harvest for dry matter yield, total $\mathrm{N}$ yield and N-15 analysis was done at the pod-filling stage on January $12^{\text {th }} 1977$, taking plants from all replicates of treatments receiving $\mathrm{N}-15$ labelled fertilizer or N-15 labelled foliar spray.

At the end of the growth cycle, on February $7^{\text {th }} 1977,20$ plants of row 5 were harvested for grain, and above ground part yield, and for $\mathrm{N}-15$ analysis. As at this stage most of the leaves were falling, the leaves, stems and husks were joined together and considered as straw.

Yield measurements were made on the plants harvested from rows 4, 5, and 6, leaving out $50 \mathrm{~cm}$ lengths at each and of the plot. The weight of grain and above ground part from the area harvested for $15-\mathrm{N}$ analysis was added on to the yield harvest data from the rest of the area harvested for yield.

\section{Observations on nodules}

Nodule observation was done at late seeding stage (4 weeks). Fcrr plants were picked at random from each of the $4 \mathrm{sub}$ plots demarcated for nodule observation in the sampling row.

\section{Plant analysis}

The plant samples were dried in a ventilated oven at 65 to $70^{\circ} \mathrm{C}$. On the ground samples, pasing through a 20 -mesh screen, total nitrogen was determined by the plant digestion procedure described by HANWAY, 1962. 
After the digestion of another portion of ground samples with nitro-perchloric acid, in suitable aliquots of the extract, phosphorus was determined by the vanadate-molybdate-yellow method, in the photocolorimeter Klett Summerson, potassium by the flame photometer of emission and sulphur by the Johnson and Nishita method. (JOHNSON and NISHITA, 1952).

Determination of the isotopic ratio ${ }^{14} \mathrm{~N} /{ }^{15} \mathrm{~N}$

The plant samples were prepared according to the Dumas method modified (PROKSCH, 1969), and the isotopic composition of $\mathrm{N}_{2}$ liberated was determined in the mass spectrometer Varian-Mat, model $\mathrm{CH}-4$, by measurement of the ion currents coresponding to mass $28\left({ }^{14} \mathrm{~N}^{14} \mathrm{~N}\right)$ and mass $30\left({ }^{15} \mathrm{~N}^{15} \mathrm{~N}\right)$.

Potential evapotranspiration (Et)

This was calculated by the method of PENMAN adapted to the conditions of Piracicaba, according to OMETTO, 1974. (FIG. 1).

\section{Cultural practices}

Weeding was done on November 30, December 15, December 28, 1976 and January 10, 1977.

Sprayings of the fungicide Antracol (Zinc-Bis-Dithio Carbamate) at the rate of $2 \mathrm{~kg} /$ ha and a concentration of $0.25 \%$ and of the inseticide Dicarbon 85 (Naftil-N-metil-carbamate) at the rate of $1.8 \mathrm{~kg} / \mathrm{ha}$ and at a concentration of $0.2 \%$ were made on November 30 , December 13 , and December 28.

\section{RESULTS AND DISCUSSION}

The fertility status of this sandy loam soil is low in exchangeable bases and CEC, but it has good physical properties. Contents of total nitrogen and soluble phosphorus are medium.

There was a good soil moisture at the seeding.

The clata obtained at the intermediate harvesting, were as expecting (Table II). Concerning the dry matter yield, the treatments which received nitrogen at seeding showed significative difference with the absolute control. The same pattern was observed in respect to the quantity of nitrogen in $\mathrm{kg} /$ ha taken up by the plant. From the v0 $\mathrm{kg}$ $\mathrm{N} /$ ha, applied at seeding, the plants utilized $5.8 \mathrm{~kg} \mathrm{~N} /$ ha. 


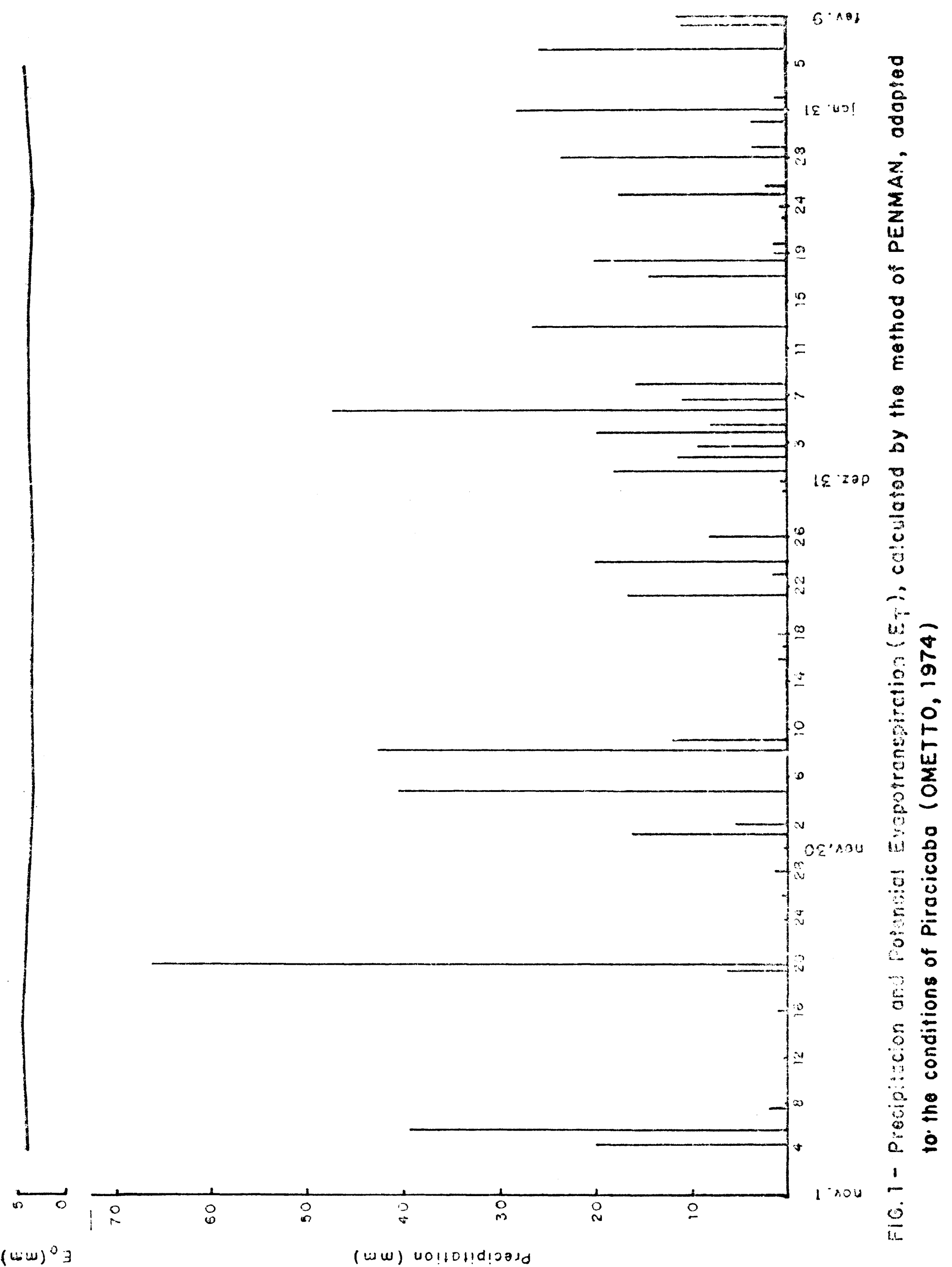


Table II - Dry plant weight ( $\mathrm{kg} / \mathrm{ha}$ ), percentage and $\mathrm{kg} / \mathrm{ha}$ of total $\mathrm{N}$, and nitrogen in the dry plant weight derived from the fertilizer (NDFF) at the pod filling stage

\begin{tabular}{cccccc}
\hline Treatment & $\begin{array}{c}\text { Dry Plant } \\
\text { Weight } \\
(\mathrm{kg} / \mathrm{ha})\end{array}$ & $\%$ Total N Kg Total N & \% NDFF & Kig NDFF \\
\hline \hline 1 & $1049 \mathrm{ab}$ & $2,29 \mathrm{~b}$ & $24,20 \mathrm{~b}$ & & \\
2 & $1040^{\mathrm{ab}}$ & $2,29 \mathrm{~b}$ & $23,77 \mathrm{~b}$ & & \\
3 & $1129 \mathrm{~b}$ & $2,27 \mathrm{ab}$ & $25,59 \mathrm{~b}$ & 22,69 & 5,83 \\
4 & $1167 \mathrm{~b}$ & $2,30^{\mathrm{b}}$ & $26,78 \mathrm{~b}$ & & 5,71 \\
5 & $1154 \mathrm{~b}$ & $2,23^{\mathrm{b}}$ & $25,72^{\mathrm{b}}$ & 22,22 & \\
6 & $1140^{\mathrm{b}}$ & $2,31^{\mathrm{b}}$ & $26,36^{\mathrm{b}}$ & & \\
7 & $1124 \mathrm{~b}$ & $2,27 \mathrm{ab}$ & $25,52 \mathrm{~b}$ & & \\
8 & $944^{\mathrm{a}}$ & $2,04^{\mathrm{a}}$ & $19,26^{\mathrm{a}}$ & & \\
\hline $\mathrm{CV} \%$ & 6,276 & 5,295 & 7,594 & & \\
$\mathrm{dms}$ & 141 & 0,24 & 3,86 & & \\
\hline
\end{tabular}

Data regarding straw and grain yield, $\%$ total $\mathrm{N}, \mathrm{kg}$ total $\mathrm{N} / \mathrm{ha}$, $\% \mathrm{NDFF}$ (nitrogen derived from the fertilizer), $\mathrm{kg} \mathrm{NDFF} / \mathrm{ha}$ and $\mathrm{EFU} \%$ (Efficiency of fertilizer utilization) are given in Table III. The treatment 6 , where the nitrogen was been applied in the soil at seeding and at the pod filling stage, excelled the othr tratments, with a grain yield of $1231 \mathrm{~kg} / \mathrm{ha}$, followed by the treatment 3 , which received only the nitrogen at seeding. The treatments $2,4,5$, and 7 which received the foliar application of the Hanway solution yielded less. This fact can be attributed to the presence of ammonium nitrate in that concentration. The composition of final spray is: $40 \mathrm{~kg} \mathrm{~N}+11.12 \mathrm{~kg} \mathrm{P}_{5} \mathrm{O}_{5}$ $+17.5 \mathrm{~kg} \mathrm{~K} \mathrm{O}+4.48 \mathrm{~S}$ per 500 litres. This is equivalent to: $228.57 \mathrm{~g}$ $\mathrm{NH}_{4} \mathrm{NO}_{3}+86.23 \mathrm{~g}$ potassium polyphosphate $+24.89 \mathrm{~g} \mathrm{~K}_{2} \mathrm{SO}_{4}$ per liter.

The visual symptoms was a general burning of the leaves. The spraying was done at noon, on January $12^{\text {th }}$. On January 17 , it was observed a recuperation of the young leaves. But, at the second foliar spraying, the leaf burn was more severe. When leaf burn occurred, photosynthesis probably has been reduced and the plant did not trarslocate added nutrients to the seeds. The high incidence of leaf burn can be attributed to the high salt index of ammonium nitrate in the application of foliar fertilizer. The application of urea, instead of ammonium nitrate would probably give better yield.

The best yield was obtained with the treatment 6 ; this means that the topdress application of ammonium nitrate at the pod filling stage is also efficient, as the foliar fertilization at the same stage. Unfortunately, the sol application of nitrogen at that stage is not too much feasible. 


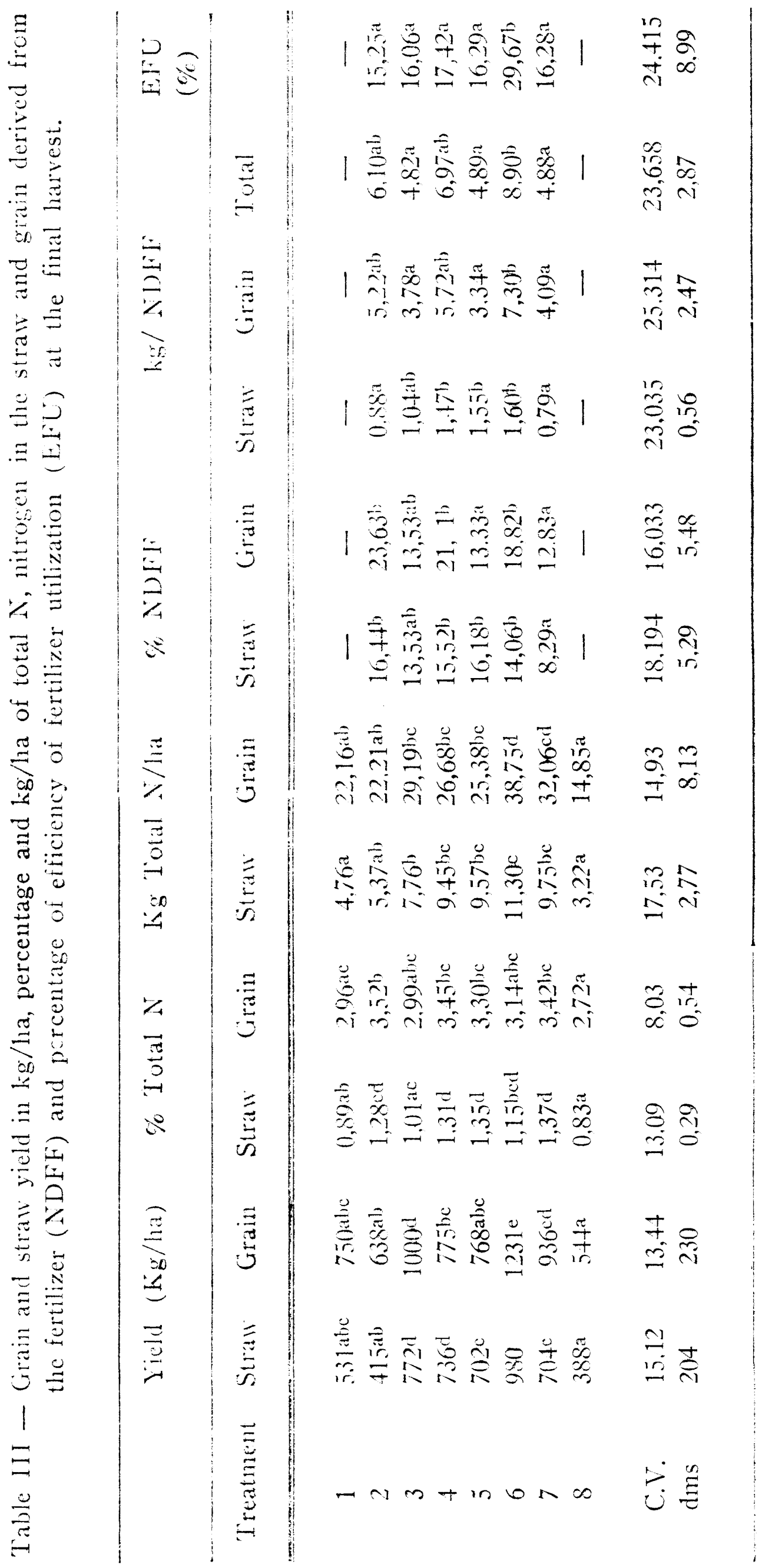


The treatment 6 showed also the better absorption of the fertilizer nitrogen and also the better efficiency of the fertilizer utilization (Table III $-6^{\text {th }}$ and $7^{\text {th }}$ columns).

Notwithstanding the severity of the leaf burn and the low grain yield, the plants of the theatments that have been sprayed indicated an EFU approximately half that of the plants in treatment 6 . It is reasonable to acept that there has been foliar nitrogen absorption.

In respect to the quantity in $\mathrm{kg} / \mathrm{ha}$ of phosphorus and potassium in the grain and in the straw derived from the fertilizers and from the soil the treatments 6 and 3 were superior to the other (Table IV).

Table IV - Percentage and $\mathrm{kg} / \mathrm{ha}$ of phosphorus and potassium in grain and straw yicld at the final harvest.

\begin{tabular}{|c|c|c|c|c|c|c|c|c|}
\hline \multirow{2}{*}{ Treatment } & \multicolumn{4}{|c|}{ G R A I N } & \multicolumn{4}{|c|}{$\mathrm{S} T \mathrm{~T} A \mathrm{~W}$} \\
\hline & $\%$ & $\mathrm{~kg} \mathrm{P} / \mathrm{ha}$ & $\% \mathrm{~K}$ & $\mathrm{~kg} \mathrm{~K} / \mathrm{ha}$ & $\% \mathrm{P}$ & $\mathrm{kg} \mathrm{P} / \mathrm{ha}$ & $\% \mathrm{~K}$ & $\mathrm{~kg} \mathrm{~K} / \mathrm{r}^{\prime} \mathrm{a}$ \\
\hline 1 & 0.51 & 3.780 & 1.50 & 11.262 & 4.15 & 0.775 & 2.04 & $\cdot 10.85$ \\
\hline 2 & 0.50 & 3.170 & 1.53 & 9.736 & 0.17 & 0.655 & 2.29 & 9.31 \\
\hline 3 & 0.48 & 4.757 & 1.44 & 14.455 & 0.13 & 0.967 & 2.08 & 16.02 \\
\hline 4 & 0.50 & 3.824 & 1.48 & 11.413 & 0.12 & 0.897 & 2.20 & 15.93 \\
\hline 5 & 0.50 & 3.835 & 1.51 & 11.625 & 0.12 & 0.835 & 2.27 & 15.92 \\
\hline 6 & 0.48 & 5.952 & 1.48 & 18.270 & 0.15 & 1.456 & 2.42 & 23.64 \\
\hline 7 & 0.45 & 4.200 & 1.46 & 13.679 & 0.13 & 0.880 & 2.25 & 15.10 \\
\hline 8 & 0.43 & 2.362 & 1.48 & 8.049 & 0.15 & 0.564 & 2.09 & 8.06 \\
\hline $\mathrm{CV} \%$ & 10.46 & 17.31 & 3.57 & 14.48 & 26.28 & 20.66 & 10.64 & 12.95 \\
\hline $\mathrm{dms}$ & - & 1.43 & - & 3.69 & - & 0.38 & - & 8.61 \\
\hline $\begin{array}{l}F(\text { Tukey } \\
5 \%)\end{array}$ & n.s. & 3.86 & n.s. & 4.31 & n.s. & 5.37 & n.s. & 3.91 \\
\hline
\end{tabular}

Regarding the weight of nodules in $\mathrm{mg}$ (Table $\mathrm{V}$ ) and the numwer of nodules per plant (Table $\mathrm{V}$ ), it can be inferred that all the treatments were nodulated, however, the coefficient of variation was extremely high $(95 \%$ and $102 \%$ for the weight and number of nodules, respectively); this invalidated any conclusion. 
Table $\mathrm{V}$ - Weight in $\mathrm{mg}$ and number of nodules per plant (average of five replicates).

Weight $(x)$ of nodules per plant Number $(y)$ of nodules per plant

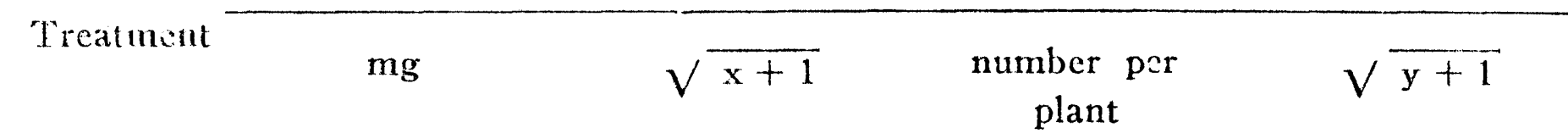

\begin{tabular}{lllll}
\hline 1 & 36 & 5.6 & 21.6 & 4.3 \\
2 & 48 & 6.3 & 44.0 & 6.0 \\
3 & 59 & 6.6 & 43.6 & 6.0 \\
4 & 32 & 5.2 & 32.2 & 5.0 \\
8 & 54 & 7.0 & 42.4 & 6.1 \\
\hline $\mathrm{CV} \%$ & 95.4 & 55.46 & 102.2 & 60.9 \\
\hline
\end{tabular}

RESUMO

EFEITOS DA ADUBAÇAO FOLIAR DO FEIJOEIRO (Phaseolus vulgaris, L.) DURANTE O ESTÁdIO DA FORMAÇÃO DOS GRÃOS

Um experimento foi conduzido com feijosiro (Phaseolus vulgaris, L.) num latossol vermelho amarelo, fase arenosa, a fim de estudar a influência da pulverização foliar de solução de nutrientes (NPKS) durante o estádio da formação de grão na: 1) produção; 2) absorção de nitrogênio do solo e do fertilizante pela cultura através do sistema radicular e 3) a eficiência pelo grão de utilização de nitrogênio contido na solução de nutrientes pulverizada.

A composição da solução era: $114,28 \mathrm{~kg} \mathrm{NH}_{4} \mathrm{NO}_{3}+43,11 \mathrm{~kg}$ polifosfato de potássio $+12,44 \mathrm{~kg}$ de sulfato de potássio por 500 litros.

Os resultados deste experimento mostraram que a aplicação foliar desta solução de Hanway com nitrato de amônio em lugar de uréia, durante o estádio da formação de grão, causou queima da fôlha e a produção de grãos foi inferior àquela das plantas que receberam uma aplicação no solo de fertilizante nitrogenado no mesmo estádio. Esses fatos podem ser atribuídos a presença de nitrato de amônio na concentração usada.

A absorção do nitrogênio do fertilizante através do sistema radicular e a eficiência da sua utilização foi maior do que daquela através das folhas. 


\section{I.ITERATURA CITADA}

BREMMER, J.M., 1965. Total nitrogen. In Black, C.A. ed. Methods of soil analysis. Part 2. Agronomy, 9: 1149.

BLENDIA, J.P.L. e NEPTUNE, A.M.L., 1971. Adubação foliar do algodoeiro (Grossypium hirsutum. L., var. I.A.C. 12), com nitrogênio, fósforo e potássio avaliada pela produção e diagnose foliar. Anais Esc. Sup. de Agric. "Luiz de Queiroz", XXVIII: 5.

BULISANI, E.A., ALMEIDA, L.D. de \& DEMATTE, J.D., 1973a. Observações preliminares sobre a adubação foliar em feijoeiro (Phaseolus vulgaris). I. Bragantia 32: XIII.

IULISANI, E.A., MIYASAKA. S. \& ALMEIDA, L.D. de, 1973b. Observações sobre a adubação foliar em feijociro (Phaseolus vulgaris, L.). II. Bragantia, 32: XXVII.

CROCOMO, O.J. e NEPTUNE, A.M.L., 1951. Estudo sobre a distribuição do S35 em cafeeiro (Coffea arabica L., Bourbon). Anais Esc. Sup. de Agric. "Luiz de Queiroz", XVIII : 169.

D'ARTAGNAN, A.L., LEITAO F.o, M.F., MIYASAKA, S., 1971. Feijoeiro no Estado de São Paulo. Circ. Inst. Agron. Campinas, n. $7: 8 \mathrm{p}$.

G.ARCIA, R.L. e HANWAY, J.J., 1976. Foliar fertilization of soybeans during the seed-filling period. Agron. J. 68: 653.

GRAY, R.C., 1977. Foliar fertilisation with primary nutrients during the reproductive stage of plant growth. Proceedings N. ${ }^{\circ}$ 164. The Fertiliser Society of London: 5.

GRIS, E., 1844. Nouvelles expériences sur l'action des composés ferrugineux soluble, appliqués à la végétation, et spécialement au traitement de la chlorose et de la débilité des plantes. Compt. Rend. Acad. Sci. (Paris), 19: 1118.

GRIS. E., 1847. Addition $\mathrm{Y}$ une précédente. Note concernant des expériences sur l'application des sels de fer à la végétation, et spécialement au traitement des plantes chlorosées, languissantes et menacées détne mort prochaine. Compt. Rend. Acad. Sci. (Paris), 25: 276.

HANWAY, J.J., 1962. Corn growth and composition in relation to soil fertility. II. Uptake of $\mathrm{N}, \mathrm{P}$ and $\mathrm{K}$ and their distribution in different plant parts during the growing season. Agron. J. 54:217.

JACKSON, M.L., 1956. Soil chemical analysis. Advanced course. Publicado pelo autor. Department of Soil Science. Univ. of Wisconsin, Madison, Wis: 50.

JOHNSON, C.M. and NISHITA, H., 1952. Microestimation of sulfur in plant materials, soils and irrigation waters. Anal Chem. 24(4):736.

NEPTUNE, A.M.L., CROCOMO, O.J., PIMENTEL GOMES, F. and CAMPOS, H., 1961. Pulverização foliar em cafeciro. II. Aplicação de adubos potássicos. Anais Esc. Sup. Agric. "Luiz de Queiroz", 18:277.

NEPTUNE, A.M.L., NAKAGAWA, J. e SCOTTON, L.C., 1967. Adubação foliar em batatinha. Revista "O Solo", Ano LIX, n. ${ }^{\circ}$ 1: 17.

OMETTO, J.C., 1974. Uma equação para a estimativa de evapotranspiração potencial: sua aplicação no cálculo das necessidades hídricas e do rendimento agro-industrial da cana-de-açícar na região de Piracicaba. Tese Docência-Livre. PIRACICABAESALQ-USP: 129 p.

PROKSCH, G., 1969. Routine analysis of ${ }^{15} \mathrm{~N}$ in plant material by mass spectrometry. Plant \& Soil, 31:380.

SILVA, N.M. da, 1969. Estudo comparativo da adubação foliar com a convencional do algodoeiro. Separata de Bragantia, 23(5): 47. 
